\title{
CATARACT SURGERY: EXPECTATIONS OF PATIENTS ASSISTED DURING A COMMUNITY PROJECT IN SÃO
} PAULO, STATE OF SÃO PAULO, BRAZIL

\author{
Newton Kara-Júnior, Edméa Rita Temporini and Newton Kara-José
}

RHCFAP/3055

KARA-JÚNIOR N et al. - Cataract surgery: expectations of patients assisted during a community project in São Paulo, state of São Paulo, Brazil. Rev. Hosp. Clín. Fac. Med. S. Paulo 56(6):163-168, 2001.

Objective: To identify social characteristics and expectations of individuals seen during a community project for the treatment of senile cataracts. Expected results from their eye surgery and its consequences to their quality of life were studied as well.

Methodology: Cataract patients (visual acuity equal to or lower than 0.2 in the more superior eye) aged 50 years or over, were surveyed by means of interviews held during their visit at the Cataract Project in São Paulo city, State of São Paulo, Brazil, in 1999.

Results: The sample was composed of 331 subjects of low socioeconomic level ranging in age from 50 to 97 years (average $=$ 71.8 years). Expectation of total recovery from the cataract condition by means of surgery was declared by $80.0 \%$ of the respondents, with no significant differences between male and female subjects $(P<0.1723)$. Hope to resume manual activities was expressed by $59.8 \%$.

Conclusion: A predominance of expectations of resuming normal activity and achieving a better quality of life after cataract surgery were identified.

DESCRIPTORS: Senile cataract. Expectations. Community project. Public health ophthalmology. Ocular health.

Cataracts are responsible for $50.0 \%$ of the cases of blindness all over the world and are estimated to occur to some extent in $50.0 \%$ of individuals aged 60 years or over and in almost all individuals aged 80 years or over ${ }^{1-4}$.

Cataract surgery, associated with implantation of an intraocular lens, is a sophisticated technological procedure that permits the rehabilitation of vision in the great majority of cases ${ }^{3}$. However, in developing countries, difficulties in accessing ophthalmologic care due both to individual and environmental factors and to obstacles set up by the health system itself prevent full utilization of the surgical procedure ${ }^{5,6}$.

The creation of the so-called "cataract-free zone" community projects in
Latin America, especially in Brazil, has been contributing to a reduction of the proportion of blindness due to cataracts, clearly showing the value of this intervention. This kind of initiative seeks to eliminate logistic obstacles to the surgical treatment of cataracts by facilitating access to eye examination - and subsequent surgery - especially for the lowincome population ${ }^{2,5}$.

This preventive action, however, requires the conscious participation of the individual affected by this eye condition in terms of adopting and/or

From the Discipline of Ophthalmology, Hospital das Clínicas, Faculty of Medicine, University of São Paulo. changing behaviors related to the surgical treatment of cataracts.

It is widely recognized that ocular health depends on multiple psycho-social-cultural factors, in addition to other aspects linked to health services. Among such factors, the individual's beliefs concerning the success of the medical procedure might affect the motivation to seek treatment. Beliefs in the area of health are usually a factor that predisposes the individual to adopt a behavior, whether appropriate or $\operatorname{not}^{7,8}$.

Accordingly, the present study was conducted to identify the social characteristics and expectations of individuals seen during that community project for the treatment of senile cata- 
racts, considering the expected outcome of the surgery and consequences for the quality of life of the patients involved.

\section{METHODS}

A survey was carried out on a population who attended a university hospital seeking the care provided by the Cataract Project on 2 consecutive days of a weekend.

The inclusion criteria for the study were: male and female individuals aged 50 years or older suffering from senile cataracts (visual acuity equal to or less than 0.2 in the better eye) who were willing to be interviewed. Therefore, the sample obtained was a nonnormal population; instead it satisfied the criterion of convenience.

A questionnaire was constructed based on preliminary studies 5 that allowed elaborate structured questions. After a previous test of the instrument carried out on a similar population, the questionnaire was filled in while the subjects were being interviewed during attendance at the Cataract Project.

The sample's demographic characteristics, expectations concerning the cataract surgery, and the expectation of resuming activities after the surgical intervention were studied. Patient occupation was classified according to the criterion of Gouveia's \& Havighurst ${ }^{9}$.

The interviews were held by previously trained medical students. Data were processed using the Epi-Info system. Statistical analysis was performed using the chi-square test at the 0.05 level of significance.

\section{RESULTS}

The sample consisted of 331 subjects suffering from senile cataracts who participated in the Cataract Project for care on 2 consecutive days of a weekend in 1999.

The distribution of sex of the sample was approximately even, with a slight predominance of women (58.6\%). Ages ranged from 50 to 97 years (mean: 71.8 years). Most subjects $(40.8 \%)$ were in the $70-79$ age bracket (Table 1).

With respect to schooling, 172 subjects $(52.0 \%)$ reported having not concluded elementary school and 133 (40.2\%) reported no schooling at all. Only 7 respondents $(2.1 \%)$ reported university education (completed or not).

Concerning occupational status, only $13.0 \%$ of the subjects exercised a remunerated activity, performing specialized (37.2\%) and non-specialized (44.2\%) manual functions. Among the latter, there was a predominance of males $(27.9 \%)$ over females $(16.3 \%)$ (Table 2).

When asked how they had found out about the care provided by the Cataract Project at the hospital, 27.6\% of the respondents stated they had heard about it on a television broadcast as the single source, and $47.0 \%$ reported a television broadcast plus other sources. It seems that friends, neighbors, and relatives also played a relevant role in the dissemination of this information, being mentioned by $39.1 \%$ of the respondents as the single

Table 1 - Distribution of the sample according to age and sex.

\begin{tabular}{|c|c|c|c|c|c|c|}
\hline \multirow{3}{*}{$\begin{array}{c}\text { Age } \\
\text { (years) }\end{array}$} & \multicolumn{4}{|c|}{ Sex } & \multirow{2}{*}{\multicolumn{2}{|c|}{ Total }} \\
\hline & \multicolumn{2}{|c|}{ Male } & \multicolumn{2}{|c|}{ Female } & & \\
\hline & $\mathrm{n}$ & $\%$ & $\mathrm{n}$ & $\%$ & \multicolumn{2}{|r|}{$\%$} \\
\hline $50 \mid-60$ & 24 & 17.5 & 21 & 10.8 & 45 & 13.6 \\
\hline $60-70$ & 37 & 27.0 & 47 & 24.2 & 84 & 25.4 \\
\hline $70-80$ & 53 & 38.7 & 82 & 42.3 & 135 & 40.8 \\
\hline $80 \mid-98$ & 23 & 16.8 & 44 & 22.7 & 67 & 20.2 \\
\hline \multicolumn{7}{|l|}{$\bar{x}=71.8$ years } \\
\hline Total & 137 & 41.4 & 194 & 58.6 & 331 & 100.0 \\
\hline
\end{tabular}

Table 2 - Occupation according to sex.

\begin{tabular}{|c|c|c|c|c|c|c|}
\hline \multirow{3}{*}{$\begin{array}{l}\text { Occupation } \\
\operatorname{Level}(*)\end{array}$} & \multicolumn{4}{|c|}{ Sex } & \multirow{2}{*}{\multicolumn{2}{|c|}{ Total }} \\
\hline & \multicolumn{2}{|c|}{ Male } & \multicolumn{2}{|c|}{ Female } & & \\
\hline & $\mathrm{n}$ & $\%$ & $\mathrm{n}$ & $\%$ & $\mathrm{n}$ & $\%$ \\
\hline I & - & - & - & - & - & - \\
\hline II & 1 & 3.3 & 1 & 7.7 & 2 & 4.7 \\
\hline III & 1 & 3.3 & - & - & 1 & 2.3 \\
\hline IV & 3 & 10.0 & - & - & 3 & 6.9 \\
\hline V & 2 & 6.7 & - & - & 2 & 4.7 \\
\hline VI & 11 & 36.7 & 5 & 38.4 & 16 & 37.2 \\
\hline VII & 12 & 40.0 & 7 & 53.9 & 19 & 44.2 \\
\hline Total & 30 & 69.8 & 13 & 30.2 & $43(* *)$ & 100.0 \\
\hline
\end{tabular}

(*) I - Political and administrative high-status positions; owners of large companies and similar ones;

II - Liberal arts professions; management or directorship positions; owners of middle-size companies;

III - Lower positions of supervision or inspection concerning non-manual occupations; owners of small commercial, industrial, farming and cattle-raising companies;

IV - Non-manual routine occupations and similar ones;

V - Supervision of manual work and similar occupations;

VI - Specialized manual occupations and similar ones;

VII - Non-specialized manual occupations.

(**) The remaining 288 subjects $(87.0 \%)$ did not exercise remunerated activities. 
source or in association with other forms. It is worth noticing that the vehicles of communication that depend on visual function, such as newspapers and booklets, were pointed out by only $9.8 \%$ and $1.3 \%$ of the respondents, respectively, representing reduced proportions (Table 3).

The level of expectation concerning the extent of solution of the eye problem by cataract surgery was high, with $80.0 \%$ of the subjects expecting a full solution. There were no significant differences between males and females $(P$ $\leq 0.1723$ ). Among those who did not believe in the efficacy of surgery, no significant differences between sexes were found for any of the alleged reasons. The predominant response was that the patient did not believe in the possibility of reversal of cataracts (8.2\%) (Table 4) .

The respondents declared multiple expectations about resuming activities after eye surgery (Table 6). They especially mentioned the possibility of performing manual tasks $(59.8 \%)$, reading (47.1\%), and watching TV (45.3\%).

\section{DISCUSSION}

Over the past few years, greater emphasis has been placed on ophthalmology in the public health arena. The application of public health principles to programs for blindness prevention significantly reduces the number of blind individuals in population groups ${ }^{10}$.

The Cataract Project is an example of public health intervention in ophthalmology in which blindness prevention is obtainable by curative means. Normally, such projects attract the attention of individuals with blindness due to different causes who are carefully screened and diagnosed.

The intense dissemination of information about this service usually results in large numbers of persons seeking specialized examination and treat-

Table 3 - Source of information concerning the care provided by the Cataract Project at the Hospital das Clinicas ( HC ), University of São Paulo School of Medicine (associate answers).

\begin{tabular}{|c|c|c|c|c|c|c|c|c|c|}
\hline \multicolumn{10}{|c|}{$\mathrm{n}=331$} \\
\hline \multirow{2}{*}{\multicolumn{2}{|c|}{ Respondents }} & \multicolumn{8}{|c|}{ Forms of Association } \\
\hline & & TV & $\begin{array}{l}\text { News- } \\
\text { paper }\end{array}$ & Leaflet & $\begin{array}{c}\text { Street } \\
\text { Banner }\end{array}$ & $\begin{array}{l}\text { Health } \\
\text { Center }\end{array}$ & $\begin{array}{l}\text { Friend, } \\
\text { Neighbor } \\
\text { Or } \\
\text { Relative }\end{array}$ & Radio & $\begin{array}{l}\text { At } \\
\text { The } \\
\text { HC }\end{array}$ \\
\hline 81 & 17.6 & 81 & & & & & & & \\
\hline 72 & 24.5 & & & & & & 72 & & \\
\hline 32 & 10.9 & & & & & & & 32 & \\
\hline 22 & 7.5 & 22 & & & & & 22 & & \\
\hline 12 & 4.1 & 12 & & & & & & 12 & \\
\hline 11 & 3.7 & & 11 & & & & & & \\
\hline 10 & 3.4 & 10 & 10 & & & & & & \\
\hline 9 & 3.1 & & & & 9 & & & & \\
\hline 9 & 3.1 & & & & & & & & 9 \\
\hline 9 & 3.1 & 9 & & & 9 & & 9 & & \\
\hline 6 & 2.0 & & & & & 6 & & & \\
\hline 5 & 1.7 & & & & & & & 5 & \\
\hline 4 & 1.4 & & & 4 & & & & & \\
\hline 4 & 1.4 & & 4 & & & & 4 & & \\
\hline 4 & 1.4 & & & & & 4 & 4 & & \\
\hline 4 & 1.4 & 4 & 4 & & & & 4 & & \\
\hline $294(*)$ & 88.8 & 138 & 29 & 4 & 18 & 10 & 115 & 49 & 9 \\
\hline
\end{tabular}

(*) The other answers are related to other forms of association given by groups of 3 or less respondents.

Table 4 - Patients' expectations, according to sex.

\begin{tabular}{lrrrr}
\hline & \multicolumn{3}{c}{ Sex } \\
\cline { 2 - 5 } Expectations & \multicolumn{2}{c}{ Male } & \multicolumn{2}{c}{ Female } \\
& $\mathrm{n}$ & $\%$ & $\mathrm{n}$ & $\%$ \\
\hline & \multicolumn{2}{c}{$(\mathrm{n}=137)$} & & $(\mathrm{n}=194)$ \\
Total solution & 104 & 75.9 & 161 & 83.0 \\
Partial solution & 18 & 13.1 & 12 & 6.2 \\
Without solution & 3 & 2.2 & 3 & 1.5 \\
Does not know & 12 & 8.8 & 18 & 9.3 \\
\hline
\end{tabular}

Table 5 - Reasons for low expectancies regarding cataract surgery, according to sex. (multiple answers possible).

\begin{tabular}{|c|c|c|c|c|}
\hline \multirow{3}{*}{ Reasons } & \multicolumn{4}{|c|}{ Sex } \\
\hline & \multicolumn{2}{|c|}{ Male } & \multicolumn{2}{|c|}{ Female } \\
\hline & $\mathrm{n}$ & $\%$ & $\mathrm{n}$ & $\%$ \\
\hline $\begin{array}{l}\text { - Does not believe in the existence of } \\
\text { a solution for cataract }(n=27)\end{array}$ & 14 & 51.9 & 13 & 48.1 \\
\hline - Does not trust physicians $(n=17)$ & 7 & 41.2 & 10 & 58.8 \\
\hline - The cure depends solely on God $(n=23)$ & 6 & 26.1 & 17 & 73.9 \\
\hline
\end{tabular}

ment. Hundreds of eye surgeries can be scheduled in the course of only one of these projects. The hope to see againand consequently to resume the activities of daily life-is usually held by all individuals who participate in vision rehabilitation projects.
Results of a recent study concerning factors hindering the performance of eye surgery in individuals with senile cataracts have suggested that the main reasons for previous exclusion from surgical intervention were associated with economic and logistic factors 5 . 
Table 6 - Subjects' expectations in relation to resuming activities after eye surgery.

\begin{tabular}{lcc} 
& & $\mathrm{n}=331$ \\
\hline Expectations (*) & $\mathrm{n}$ & $\%$ \\
\hline Performance of manual tasks (sew, cook, fix appliances) & 198 & 59.8 \\
Reading newspapers/magazines & 156 & 47.1 \\
Watching TV & 150 & 45.3 \\
Going out by himself/herself & 143 & 43.2 \\
Taking a bus & 137 & 41.4 \\
Writing & 123 & 37.2 \\
Going shopping & 122 & 36.9 \\
Visiting friends & 120 & 36.3 \\
Working just like he/she did before & 114 & 34.4 \\
Doing homework & 108 & 32.6 \\
Choosing clothes to wear & 71 & 21.5 \\
Taking a bath by himself/herself & 57 & 17.2 \\
Getting dressed by himself/herself & 56 & 16.9 \\
Driving a car & 55 & 16.6 \\
\hline
\end{tabular}

(*) Multiple answers. Nine (9) respondents stated they did not know.

However, it should be pointed out that overcoming these barriers should be allied with the individual's inner disposition and spontaneous action in seeking the ophthalmologic care provided by the Cataract Project or by other community medical services.

The personal characteristics of the sample indicate that this was an elderly population (average age: 71.8 years) with low schooling, exercising no remunerated activities or else performing manual functions that, in general, do not require specialized skills. This elderly population is of a low socioeconomic level, like others reported in studies related to attendance at the Cataract Project ${ }^{5,6}$. Thus, we can state that the Project has been meeting the programmed objective of assisting the needy population.

As expected, the main source of dissemination of information concerning the Cataract Project was TV broadcasting and by word of mouth among friends/acquaintances. Written messages were mentioned by few subjects, which suggests that when publicizing a work of this kind, other means than written matter (for example, radio) should be used for enlightening the population and sending messages, since non-written modalities do not depend on visual function.

The high degree of credibility attributed to the surgical treatment of cataracts revealed by the individuals' confidence in its curative outcome (Table 4 and 5) must have been also a motivating factor for the subjects seeking that treatment. The results suggest that hope and optimism were decisive to help overcome social barriers, producing the desired preventive behavior.
Among those who showed some degree of disbelief of the potential for a positive outcome from surgical intervention, the statement that "the cure depends only on God" (6.9\%) agreed with the results obtained in a previous study in which $41.4 \%$ of the subjects attributed the onset of cataracts to God's will ${ }^{11}$. That way of thinking might give rise to a feeling of resignation, preventing the individuals from seeking specialized treatment.

The expectations manifested by the respondents, however, seem to reinforce the feeling of optimism and the belief in the success of the medical treatment they sought.

Public health intervention in the form of a community project for vision rehabilitation produces results that, in addition to preventing blindness, have an impact on the quality of life of the individuals as well as on that of the community as a whole. The identification of social-behavioral factors permeating groups and influencing individual and collective behavior should be a regular effort in the planning and implementation of programs for ocular health.

Knowledge about how individuals perceive eye health should be obtained before planning preventive actions and programs in ophthalmology ${ }^{7}$. Socialeducational diagnosis, by permitting the identification and understanding of relevant variables, also permits more successful management of health interventions.
KARA-JÚNIOR N e col. - Cirurgia de Catarata: expectativas de pacientes atendidos por projeto comunitário em São Paulo, estado de São Paulo, Brasil. Rev. Hosp. Clín. Fac. Med. S. Paulo 56(6):163-168, 2001.
Objetivo: Identificar as características sociais e as expectativas de indivíduos atendidos por projeto comunitário para tratamento da catarata senil, em relação aos resultados da cirurgia ocular e de suas conseqüências para melhor qualidade de vida.

Métodos: Realizou-se pesquisa, em que se entrevistaram pacientes de 50 anos ou mais, portadores de catarata (com acuidade visual igual ou inferior a 0,2 no olho melhor), durante o aten- 
dimento prestado por Projeto Catarata, em São Paulo em 1999.

Resultados: A amostra foi formada por 331 sujeitos, com idades entre 50 e 97 anos (médias $=71,8$ anos), de reduzido nível sócio-econômico. A expectativa de resolução total da catarata por meio da cirurgia foi declarada por $80,0 \%$ dos entrevistados, sem diferença significativa entre os sexos $(p$ $<0,1723$ ). A esperança de retomar atividades normais foi externada por $59,8 \%$.

Conclusão: Foram identificadas expectativas em relação à retomada de atividades após o esperado sucesso da cirurgia ocular, significando, sobretudo, melhora da qualidade de vida.

\section{DESCRITORES: Catarata senil.} Expectativas. Projeto comunitário. Oftalmologia em saúde pública. Saúde ocular.

\section{REFERENCES}

1. JAVITT JC, WANG F \& WEST SSK - Blindness due to cataract: epidemiology and prevention. Ann Rev Pub Health 1996;17:159177.

2. KARA-JOSÉ N(Org.) - Prevenção da cegueira por catarata. Campinas, Ed. UNICAMP, 1996. p. 19-35.

3. ELLWEIN LB \& KUPFER C - Strategic issues in preventing cataract blindness in developing countries. Bul World Health Org 1995;73:681-690.
4. THYLEFORS B, NÉGREL AD, PARARAJASEGARAM R et al. Global data on blindness. Bul World Health Org 1995;73:115121.

5. KARA-JOSÉ N \& TEMPORINI ER - Cirurgia de catarata: o porquê dos excluídos. Rev Panamericana de Salud Publica 1999;6:242248.

6. KARA-JOSÉ N, ARIETA CEL, TEMPORINI ER et al. - Tratamento cirúrgico de catarata senil: óbices para o paciente. Arq Bras Oftalmol 1996;59:573-577. 
7. TEMPORINI ER \& KARA-JOSÉ N - Níveis de prevenção de problemas oftalmológicos: propostas de investigação. Arq Bras Oftalmol 1995;58:189-192.

8. GREEN LW \& KREUTER MW - Health promotion planning - an educational and environmental approach. 2nd ed. Mountain View, Mayfield, 1991.

9. GOUVEIA AJ \& HAVIGHURST RJ - Ensino médio e desenvolvimento. São Paulo, Melhoramentos/EDUSP, 1969.
10. SCHWAB L - Public health, preventive care, and eye care delivery and evaluation. In: SCHWAB L. Eye care in developing nations. 3rd ed. San Francisco, The Foundation of the American Academy of Ophthalmology, 1999. p. 3-17.

11. TEMPORINI ER, KARA-JOSÉ N \& KARA-JUNIOR N - Catarata senil: características e percepções de pacientes atendidos em projeto comunitário de reabilitação visual. Arq Bras Oftalmol 1997; 60:79-83.

Received for publication on November 03, 2000 